\title{
Pulsus Group, the Canadian Association of Gastroenterology and CDDW
}

$\mathrm{T}_{\mathrm{w}}^{\mathrm{h}}$ he sixth annual winner of the Dr ABR Thomson - Dr CN Williams Award was announced by Robert Kalina, Publisher of The Canadian Journal of Gastroenterology, at the recent Canadian Digestive Diseases Week in Banff, Alberta. Dr KarenWong was awarded the prize for her paper "The diversity of liver diseases among outpatient referrals for an elevated serum ferritin" (Can J Gastroenterol 2006;20[7]:467-70).

This award was initiated in 2002 by Pulsus Group in honour of Drs Alan Thomson and Noel Williams, the founding CoEditors-in-Chief of The Canadian Journal of Gastroenterology, who served from 1987 to 2000. It is given annually to an

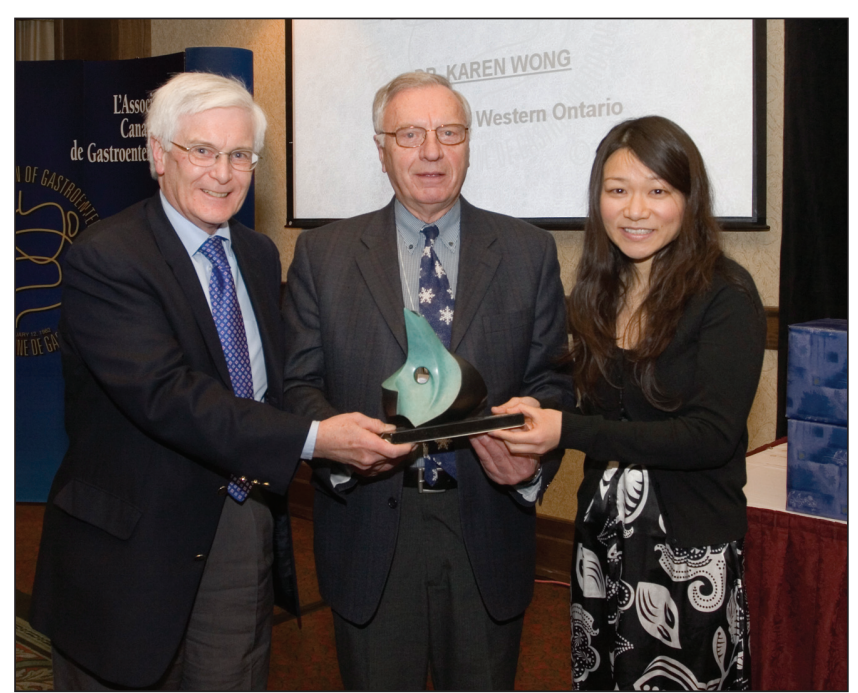

Dr Alan Thomson and Dr Noel Williams presenting the Dr ABR Thomson - Dr CN Williams award to Dr Karen Wong individual who made a significant contribution to the field of gastroenterology, as demonstrated by the impact of original research published in The Canadian Journal of Gastroenterology and judged by the Editor-in-Chief and Associate Editors. It consists of \$1,000 and a Canadian work of art.

Robert Kalina also presented a cheque to Dr William Paterson, President of the Canadian Association of Gastroenterology (CAG). The Canadian Journal of Gastroenterology is the official journal of CAG and each year, Pulsus Group contributes a percentage of revenues derived from the Journal to the Association for use in future research.

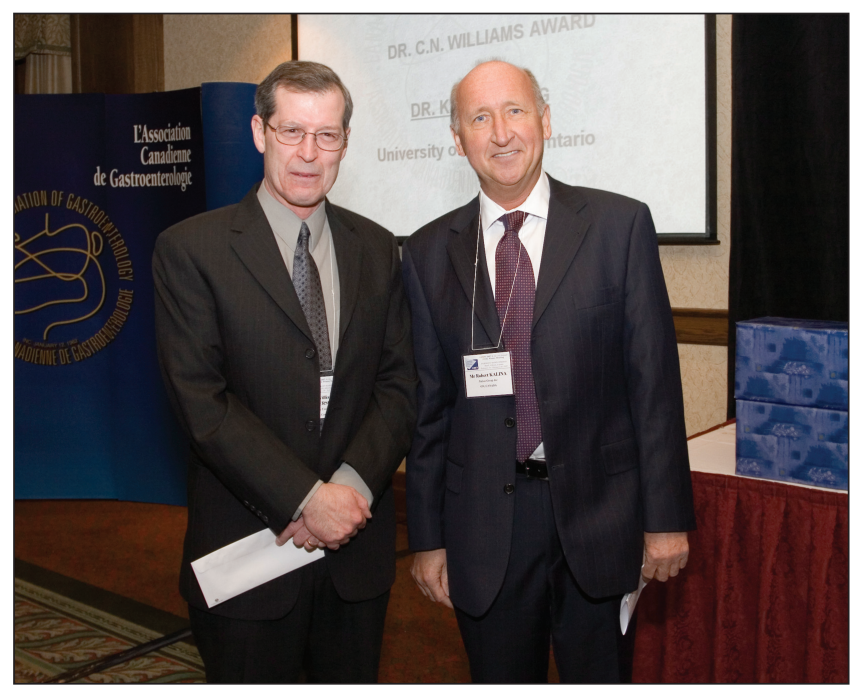

Dr William Paterson, President of the Canadian Association of Gastroenterology, receives a cheque from Robert Kalina, Publisher of The Canadian Journal of Gastroenterology 


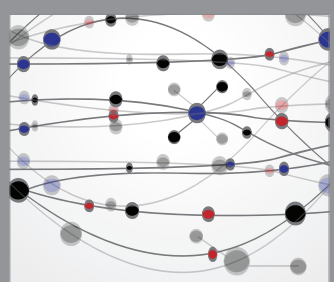

The Scientific World Journal
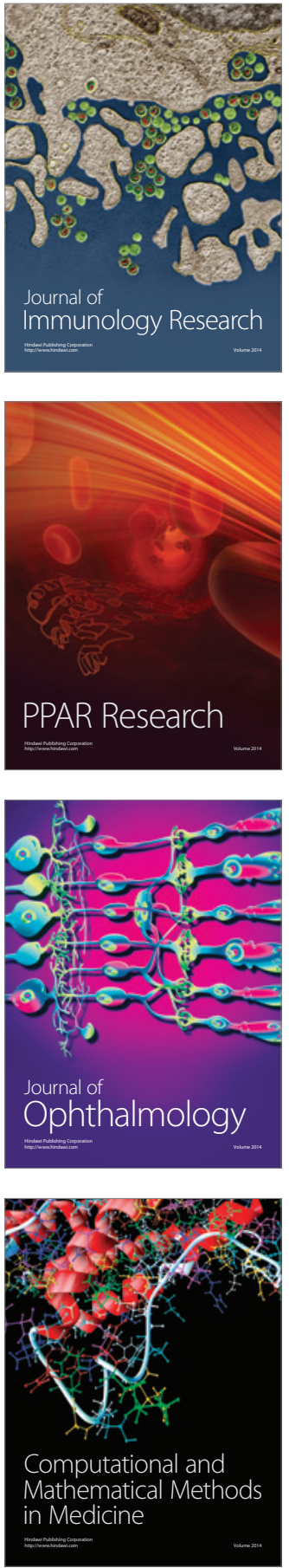

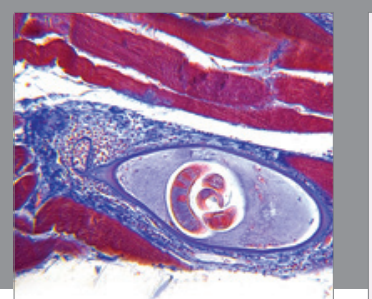

Gastroenterology Research and Practice

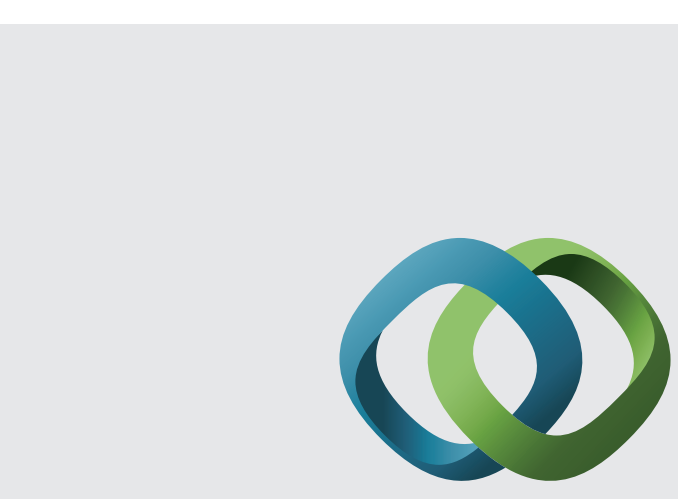

\section{Hindawi}

Submit your manuscripts at

http://www.hindawi.com
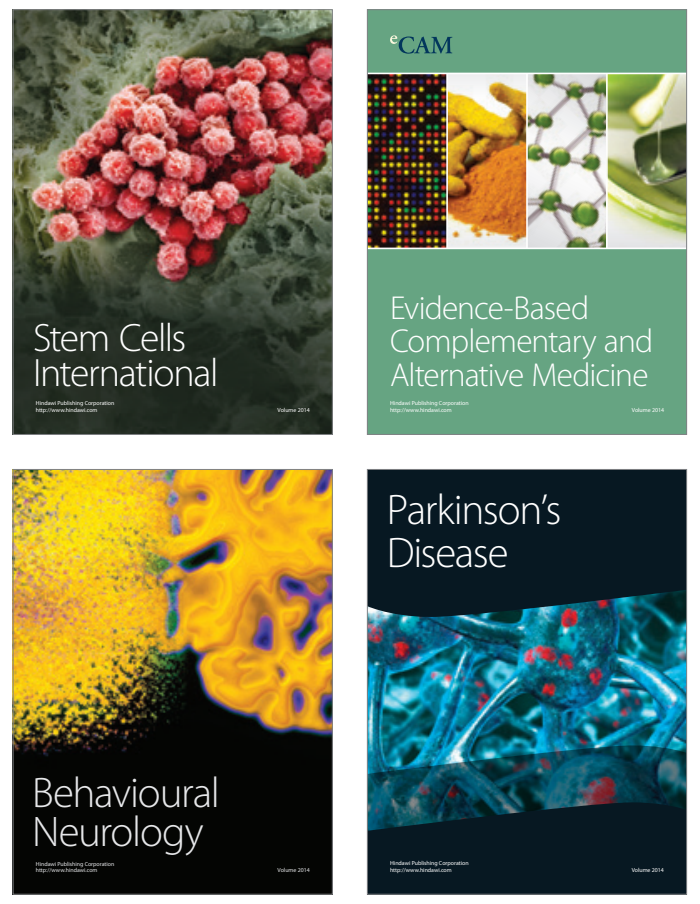
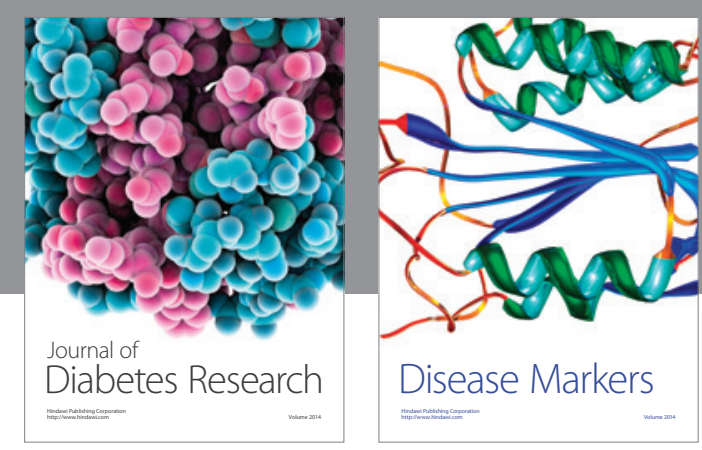

Disease Markers
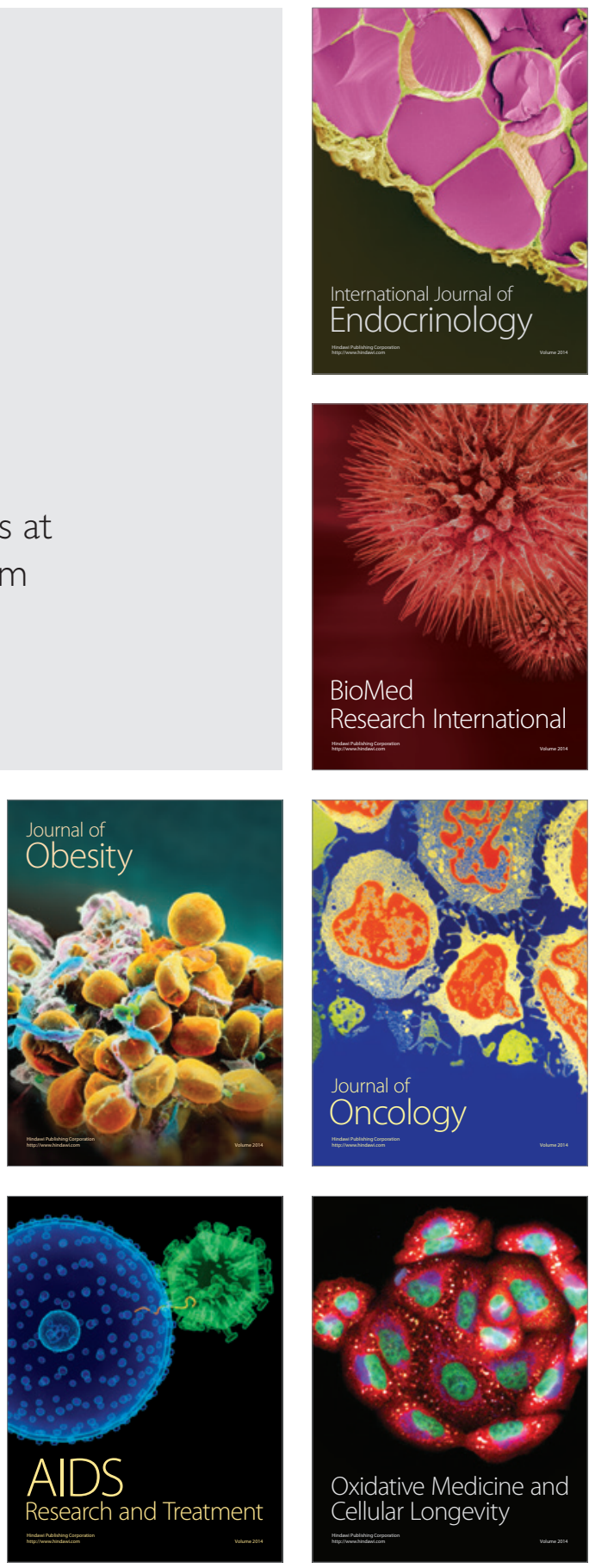